RESEARCH ARTICLE

\title{
Positioning Undergraduate Teaching and Learning Assistants as Instructional Partners
}

Hannah Jardine, Teaching and Learning Transformation Center, University of Maryland-College Park, USA

Contact: hjardine@umd.edu

\section{ABSTRACT}

Undergraduate teaching and learning assistants (UTLAs) can help to implement studentcentered learning and collaborate with faculty as instructional partners. Researchers have documented the benefits of student-faculty instructional partnerships, but additional research is necessary to better understand how UTLA-faculty partnerships are established and sustained. In this study, I explored how UTLAs are positioned in interactions with faculty for two undergraduate courses at a large, public research institution over the Fall 2018 semester. This in-depth examination revealed UTLAs may be positioned as students, informants, consultants, co-instructors, or co-creators. Positioning of UTLAs changed moment-by-moment, and the different positions were not always mutually exclusive. Thus, UTLA-faculty partnerships are complex and dynamic; even when ranking or characterizing partnerships broadly, considering variety and fluidity in positioning may help uncover the nuances behind different partnerships. This research provides insight into the interactions of collaborative UTLA-faculty instructional partnerships and the factors that may affect those interactions.

\section{KEYWORDS}

student-faculty partnerships, learning assistant, positioning theory, undergraduate biology education

In order to support student-centered instruction at the post-secondary level, instructors may integrate undergraduate teaching and learning assistants (UTLAs ${ }^{1}$ ) into their courses (Gafney \& Varma-Nelson, 2008; Miller, Groccia, \& Miller, 2001; Otero, Pollock, \& Finkelstein, 2010). UTLAs support student learning through various roles, including facilitating active engagement and student discussion in lecture (Jardine \& Friedman, 2017; Otero et al., 2010), evaluating students' work (Preszler, 2009), and assisting students outside of class (Close, Conn, \& Close, 2016; Kopp, 2000). Undergraduate courses with UTLA support demonstrate greater student academic achievement (Pavlacic, Culp, Harvey, Cathey, \& Buchanan, 2018; Preszler, 
2009), increased student articulation of reasoning (Knight, Wise, Rentsch, \& Furtak, 2015), and improved student understanding of course concepts (Otero et al., 2010).

Beyond helping to enact student-centered instruction, UTLAs also can work with faculty to improve teaching and learning. A growing body of literature explores student-faculty partnerships in teaching and learning, or reciprocal relationships where students and faculty work together towards improving teaching and learning (Cook-Sather, Bovill, \& Felten, 2014; Healey, Flint, \& Harrington, 2014; Little, 2011; Mercer-Mapstone et al., 2017; Werder \& Otis, 2010). Scholars have begun to explore partnerships between faculty and learning assistants (LAs) more specifically, and emerging research demonstrates that partnerships vary in level of collaboration (Sabella, Van Duzor, \& Davenport, 2016). These scholars have begun to investigate what occurs during LA-faculty meetings (Davenport, Amezcua, Sabella, \& Van Duzor, 2017), but additional research is necessary to better understand how interactions between UTLAs and faculty influence the development and maintenance of UTLA-faculty instructional partnerships.

In this study, I addressed the empirical question: In what ways are UTLAs positioned in interactions with faculty? I used positioning theory (Harré, Moghaddam, Cairnie, Rothbart, \& Sabat, 2009; van Langenhove \& Harré, 1999) as a framework; thus, I considered the rights, duties, and obligations (positions) distributed among people in changing patterns (storylines) as they engaged in particular kinds of actions (acts). I examined audio recordings of meetings and e-mail conversations between two different faculty members and their UTLAs, collected over the course of the Fall 2018 semester, and supported my interpretations using interviews, observations, and artifacts. This research helps to uncover interactional features (e.g., word choice, body language, conversation topics) of collaborative UTLA-faculty instructional partnerships and provide insight into the contextual factors (e.g., UTLA role and pedagogical training, instructor experience, meeting structure) that may affect those interactions.

\section{STUDENT-FACULTY PARTNERSHIPS IN TEACHING AND LEARNING}

UTLA-faculty instructional partnerships are a unique type of student-faculty partnership, in that UTLAs are students partnering with a faculty member to fill an instructional role. Overall, student-faculty partnerships reconsider the traditional divide between teacher and learner and provide both with opportunities to better understand and engage in student-centered educational practices where student ideas and experiences are the focus (Bovill, Cook-Sather, \& Felten, 2011; Cook-Sather, 2008, 2009, 2010, 2011a, 2011b; Healey et al., 2014; Sorenson, 2001). Student-faculty partnerships may lead to the availability of courses that result in deeper, more meaningful, and more equitable learning experiences for students (Bovill et al., 2011; Cook-Sather et al., 2014; Mercer-Mapstone et al., 2017). Students that participate in partnerships demonstrate an increase in confidence, motivation, and enthusiasm for learning (Bovill et al., 2011; Cook-Sather, 2010, 2011a) and experience a greater sense of belonging (Astin, 1993; Kuh, Kinzie, Schuh, \& Whitt, 2010; Tinto, 1993). Faculty that engage in partnerships reap practical, emotional, and intellectual benefits, including improved teaching practice, greater understanding of students' experiences, and values more strongly associated with teacher identity (Bovill, 2014; Cook-Sather, 2008, 2011a, 2014; Felten et al., 2013).

Student-faculty partnerships may vary in focus and level of collaboration (Cook-Sather et al., 2014; Healey et al., 2014), and researchers have explored specifically how UTLA-faculty 
instructional partnerships vary. UTLAs meet regularly with faculty to plan, cover content, and share concerns, and these meetings play out in a variety of ways. Sabella et al. (2016) characterized three levels of LA-faculty partnerships: mentor-mentee partnerships, facultydriven collaboration, and full collaboration. Mentor-mentee partnerships were one-directional with limited LA input, where meetings consisted mostly of faculty reviewing content and introducing activities. In faculty-driven collaboration, faculty elicited feedback and insights from LAs, but faculty were still in control of LA involvement. Collaborative partnerships resulted when faculty members shared control with the LAs, who were willing and able to make substantive suggestions and contributions to help improve the course. Sabella et al. (2016) suggested that the nature of the LA-faculty interactions likely depended on faculty members' and LAs' views of their respective roles as well as LAs' aspirations and abilities.

\section{THEORETICAL FRAMEWORK: POSITIONING THEORY}

I used positioning theory (van Langenhove \& Harré, 1999) as a framework to explore how UTLA-faculty instructional partnerships were established through interactions between UTLAs and faculty. There are three fundamental aspects of positioning theory (Harré \& Moghaddam, 2003; Harré et al., 2009; van Langenhove \& Harré, 1999):

1. Positions: Rights, duties, obligations, and associated expectations distributed among people in changing patterns (storylines) as they engage in performing particular kinds of actions (acts);

2. Acts: Spoken, written, or other communicative acts through which positions are enacted; and

3. Storylines: Patterns or narratives created through acts and positions.

For example, UTLAs and faculty positioned as co-creators might enact that position through collaborative group discussion about the design of a certain assignment, under the storyline that the UTLA role involves creating instructional materials with the faculty member. These three fundamental aspects are overlapping and interconnected (see Figure 1).

\section{Figure 1: Three aspects of positioning theory}

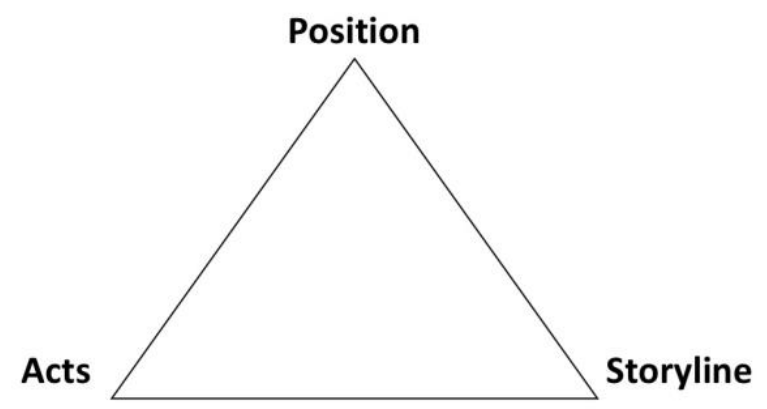

Adapted from van Langenhove \& Harré, 1999. 
Positioning theory suggests that the process of positioning happens through interactions between individuals, and positions are influenced by the time and context in which the individuals are situated (Harré et al., 2009); therefore, I examined the positioning of UTLAs by studying the spoken, written, and other communicative acts between two faculty members and their UTLAs over the course of a semester. For this study, I adopted the perspective that positioning can be examined from both a macro and micro perspective (Anderson, 2009), in that I considered UTLA positioning through summarizing general patterns of interaction as well as analyzing more specific moment-to-moment interactions.

\section{METHODS}

\section{Research settings}

The data come from two different UTLA-supported undergraduate science courses at a large, public research university in the mid-Atlantic region of the United States. I chose these two cases because I had prior relationships with the instructors, so I had reason to believe they would be information rich in regards to my research questions. In addition, I had already established a level of comfort and familiarity with the courses and the faculty members, which allowed for more profound data collection and analysis (Merriam, 1998). All participants have been given a pseudonym to protect their identities.

Case 1: Cell Biology in a living-learning program (LLP)

During class sessions for the Cell Biology course, taught by faculty member Dr. Cell, five UTLAs circulated around the lecture hall and guided student groups through activities. The UTLAs also held office hours where they led group discussions about content and homework. In addition, UTLAs were responsible for grading homework and exams. The UTLAs met weekly with Dr. Cell to discuss upcoming activities, share insights, and work on course materials. Additionally, the UTLAs engaged in a one-credit pedagogy course to support their professional development, which was also taught by Dr. Cell.

\section{Case 2: Introductory Genetics}

The UTLAs for Genetics were responsible for independently leading a 2-hour weekly discussion section, which aligned with lecture meetings led by the course instructor, faculty member Dr. Genetics. The UTLAs also graded student work and held weekly office hours. Dr. Genetics met with the UTLAs each Friday afternoon in preparation for the upcoming week to discuss content, facilitation plans, successes, and challenges.

Although my aim was not to conduct a cross-case comparison between the two cases, they exhibited notable contextual differences (summarized in Table 1) that provided opportunities to analyze how context might impact UTLA-faculty partnerships (Healy \& Healy, 2018). 
Table 1. Summary of basic descriptive information for Case 1 and Case 2

\begin{tabular}{|l|l|l|}
\hline & CASE 1: CELL BIOLOGY IN LLP & CASE 2: GENETICS \\
\hline UTLAs & 5 UTLAs, all new & 11 UTLAs, all returning \\
\hline Instructor & $\begin{array}{l}\text { Dr. Cell, first time teaching course, } \\
\text { experienced in education } \\
\text { research, administrator for LLP }\end{array}$ & $\begin{array}{l}\text { Dr. Genetics, multiple semesters of } \\
\text { experience teaching the course }\end{array}$ \\
\hline UTLA Role & $\begin{array}{l}\text { Facilitate small-group discussion } \\
\text { during large lecture, lead office } \\
\text { hours, grade homework and } \\
\text { exams }\end{array}$ & $\begin{array}{l}\text { Independently lead discussion } \\
\text { section, lead office hours, grade } \\
\text { coursework and exams }\end{array}$ \\
\hline $\begin{array}{l}\text { Pedagogy Course } \\
\text { for the UTLAs }\end{array}$ & $\begin{array}{l}\text { One-credit, 14-week course, } \\
\text { during first semester as UTLA, } \\
\text { taught by Dr. Cell }\end{array}$ & $\begin{array}{l}\text { One-credit, 10-week course, during } \\
\text { first semester as UTLA, taught by } \\
\text { other biology faculty member }\end{array}$ \\
\hline $\begin{array}{l}\text { UTLA-Faculty } \\
\text { Preparation } \\
\text { Meeting }\end{array}$ & $\begin{array}{l}\text { Weekly 1-hour meeting on } \\
\text { Thursday evenings, following } \\
\text { pedagogy course meeting }\end{array}$ & $\begin{array}{l}\text { Weekly meeting, approximately 45 } \\
\text { minutes long, Friday afternoon } \\
\text { directly before Genetics lecture } \\
\text { course }\end{array}$ \\
\hline
\end{tabular}

\section{Data sources}

This study employed ethnographic data-collection methods, which included participant observation, artifact collection, and interviewing, while focusing on specific instances of interactions collected through audio and video recording. I attended all scheduled, in-person meetings that occurred during Fall 2018 between the faculty members and their UTLAs and collected field notes and audio recordings. I recorded video at some meetings, so I had a record of how UTLAs and faculty arranged themselves in the room and the typical body language of the UTLAs and faculty. During observations, I acted as a participant observer (Merriam, 1998), in that my main role was to observe, but I interacted with the UTLAs and faculty as appropriate to build rapport and better understand the situation. Since I attended all meetings throughout the semester, my presence was part of the norm; therefore, the researcher impact was likely minimal.

In addition to observations and recordings of meetings, I gathered written artifacts relevant to understanding each case, including UTLA reflections, syllabi, course assignments, and handouts used to guide the UTLA-faculty meetings. The instructors forwarded me all e-mail communication between them and their UTLAs, and I downloaded and compiled these exchanges. I also conducted one-on-one, semi-structured interviews with instructors at the beginning and end of the semester and with UTLAs during the semester.

\section{Data analysis}

Data analysis was ongoing during and after data collection. Over the semester, I continually wrote memos with themes from observations and ideas to pursue in subsequent data-collection activities, such as potential interview questions or additional artifacts to collect (Merriam, 1998). After data collection was completed, I began to "consolidate, reduce, and interpret" (Merriam, 1998, p. 178) the data. First, I reviewed all observational field notes and 
memos to create a general description of interactional norms for each case. Then, I analyzed transcripts of audio recordings using an open constant comparative coding method (Miles \& Huberman, 2014; Strauss \& Corbin, 1990) to generate categories and themes related to ways UTLAs were positioned in moment-to-moment interactions. This coding process was inductive and iterative, in that I developed initial interpretations and findings from the data and reworked those interpretations and findings as I analyzed more data. I used data collected through ethnographic methods (e.g., participant observation, artifacts) and interviews to support analysis.

\section{UTLA-FACULTY INTERACTIONAL NORMS}

Positioning can be examined from both a macro and a micro perspective (Anderson, 2009). Thus, I start at the macro level by presenting a rich description of the overarching interactional norms for the two cases.

\section{Case 1: Open discussion amongst a teaching team}

The UTLAs and Dr. Cell met every Thursday evening in a classroom located in the dormitory building for the living-learning program, where they gathered around one large table. Dr. Cell sat amongst the UTLAs as if she were an equivalent member of the group. Use of the terms "we," "us," and "together" were very common, and Dr. Cell regularly provided the UTLAs with opportunities to discuss opinions, make decisions amongst themselves, and share personal experiences. Dr. Cell was the recognized leader of the meetings, in that she determined the topic of discussion or task to be accomplished, but the UTLAs did the majority of the talking. As one UTLA, Gabe, said in an interview, "She really makes it feel like we're a team as opposed to, I guess, just follow the leader."

The meetings began with the 1-hour pedagogy course sessions, which felt more like a class than a meeting, as the UTLAs completed assignments to support their development and came prepared to discuss assigned readings. Still, the sessions were highly discussion-based and relatively open-ended. Although the course had a set curriculum, Dr. Cell asked the UTLAs what topics they were interested in, what they liked or did not like about the course, and how it could be improved.

At the conclusion of the pedagogy course sessions each week, the group began to discuss logistics and issues for the Cell Biology course, or as Dr. Cell said in an interview, "This is what the team is doing this week." Dr. Cell typically started the meeting informally by passing out upcoming assignments and discussing thoughts about implementation. However, she would always follow up her plan by asking the UTLAs for their opinions and suggestions. In the interviews I conducted to supplement observational data, both the UTLAs and Dr. Cell noted that meetings were a time to provide each other with feedback.

\section{Case 2: Teaching-team gathering to review responsibilities}

Since the Genetics course's UTLAs individually led their own discussion sections, the Friday afternoon meetings between the UTLAs and Dr. Genetics served as a space for them to debrief and review issues, and for the UTLAs to attain information and support necessary to prepare for the coming week. As one UTLA put it in an interview, 
The purpose for those meetings is to make sure everyone's on the same page for what's to come in the next week. It's a good time to touch base on how discussion went the week before because she always wants input. . . . So it's definitely a good time to give feedback on how the week went. And then in terms of preparing for the next discussion ... at that moment we can go over questions we have or problems we foresee.

The meetings were very structured and organized, but at the same time comfortable and casual.

The meetings were held in one of the classrooms where the UTLAs taught their discussion sections. Tables were arranged in rows that faced the front of the room where there was a whiteboard and projector screen, and each seat had its own computer monitor. Through this arrangement, the UTLAs were able to follow along on their computer screens and put themselves in their students' shoes while Dr. Genetics talked through the upcoming activities. Dr. Genetics sat at a designated instructor desk, at the side of the room, and remained seated throughout the meeting to feel at an equal level and connected with the UTLAs. All of the chairs in the room could be easily moved and rotated, so despite the computer screens occasionally blocking the view between the UTLAs and Dr. Genetics, eye contact was frequent. There was an overall feeling of friendliness and support amongst all of the UTLAs and Dr. Genetics.

Dr. Genetics prepared a handout to guide each meeting, which included an overview of the coming week's activities, reminders related to course logistics, and suggestions for announcements to send to students. Although Dr. Genetics took up the majority of the speaking time, the UTLAs seemed engaged and included. Throughout the meeting, Dr. Genetics asked for their perspective on students' performance or the design and implementation of future activities and assignments. She used the terms "we" and "us" when discussing the course plan, and she regularly shared her reasoning behind instructional decisions. She mentioned areas for flexibility in the UTLAs' teaching, and frequently emphasized their experience with statements such as "you've all done this before." At various points, the UTLAs discussed their teaching and made teaching decisions among themselves.

\section{UTLA POSITIONING}

The brief descriptions above served to summarize the interactional norms for two cases of UTLA-faculty interactions explored in this study. Below, I dig deeper into each case to illustrate how UTLAs were positioned moment-to-moment during the interactions and provide detailed examples to supplement the descriptions. UTLAs were positioned in generally five ways: as (a) students, (b) informants, (c) consultants, (d) co-instructors, and (e) co-creators. These positions were not fixed for any setting, time, or individual, nor were they mutually exclusive.

This additional analysis demonstrates that even when UTLAs and faculty have established relatively stable interactional norms, UTLAs are not always positioned the same way. Thus, instead of assigning overarching characterizations to partnerships, it is worth considering how UTLA-faculty partnerships might be a more fluid mix of different characterizations, depending on time and context (Healy \& Healy, 2018). 


\section{UTLAs as students}

UTLAs are, first and foremost, undergraduate students. They spend a significant amount of time in classrooms, answering to authority, and learning from those who are considered more expert in the discipline. As well, they most likely have less teaching experience than the faculty they work with. Thus, reasonably, the UTLAs were often positioned as students, in that expectations for behavior were to listen to the faculty member, follow directions, complete assignments, or answer questions posed by the faculty member. Most often, the faculty member was the one to position the UTLAs as students by explaining concepts, giving directions, or providing teaching-related advice; however, at times, the UTLAs would position themselves as students by behaving the way they would in a classroom.

Dr. Cell and Dr. Genetics often took on the responsibility of explaining logistics or biology concepts to UTLAs while UTLAs behaved as if they were in a classroom. Most of the time, when the faculty members explained something to the UTLAs, they spoke for extended periods of time while the UTLAs listened. However, sometimes, these explanations involved back and forth discussions while the UTLAs asked questions for clarification and follow-up.

Beyond giving directions and explaining concepts, Dr. Cell and Dr. Genetics took time to communicate pedagogical advice to the UTLAs. During every pedagogy class session, Dr. Cell facilitated discussions around education topics and readings, pointed out when and why she was making certain pedagogical decisions, and shared resources about teaching. This modeling started on the first day; after engaging the UTLAs in an icebreaker, Dr. Cell told the UTLAs: "Different techniques I will try to make explicit when I'm doing them so notice we did the icebreaker first." Dr. Cell shared resources with the UTLAs, such as a list of active learning strategies and examples of questioning techniques.

Although Dr. Genetics did not teach the pedagogy course that her UTLAs took, she still sometimes shared pedagogical advice with her UTLAs. For example, before they led review sessions for the first exam, she told them in their preparation meeting: "When you're doing practice problems this week you should use questioning strategies that are inclusive and not just letting one or two people dominate the conversation." To support this statement, she included resources on the UTLAs' weekly handout.

\section{UTLAs as informants}

The UTLAs regularly informed the faculty what students were saying and doing in class and in UTLA-led office hours. Sometimes, the instructor explicitly asked the UTLAs to report on how things were going. At other times, the UTLAs positioned themselves as informants by sharing information related to students' learning and academic performance with the faculty, even when not explicitly asked. The UTLAs occasionally provided information gathered from situations and contexts where instructors would not have been present, such as the dormitory lounge, before and after class, or the back of the classroom.

In both Case 1 and Case 2, the UTLAs positioned themselves as informants after the instructor asked questions such as "How are things going?" or "How was last week?" Typically, both Dr. Cell and Dr. Genetics would start their meetings by asking this question or a similar question. The UTLAs responded by sharing how things went in class logistically, how students felt about an activity, or how students behaved. 
Sometimes, the UTLAs positioned themselves as informants even when they weren't explicitly asked to report on how things were going. For example, when talking through the final exam, Dr. Cell shared a list of possible exam questions. One UTLA, Kristen, informed her that the students were not understanding a concept, based on her conversation with the students during office hours:

Kristen: I was a little worried about junctions with them. It's not going so hot. . . I just think it's like really complicated and they're feeling a little lost. The people who just ... I feel like a little swimming in the water with the homework just kind of like.... Dr. Cell: Oh, wow! Ok! Good to know!

Dr. Cell's enthusiastic response demonstrated that she appreciated the information. In an interview, Kristen mentioned, "I think all of us are super comfortable telling her anything we might be hearing or anything we might think because she is so receptive to it," which corroborates the interpretation that Dr. Cell is appreciative of their insight.

Both Dr. Cell and Dr. Genetics noted that they gained valuable insights through the accessibility and approachability of the UTLAs. In an interview, Dr. Cell stated, "because they're peers, they're going to be a little bit more approachable than I would be to a certain extent. When there are issues in the class, they'll hear probably the grumblings before I do." Dr. Genetics expressed similar thoughts by stating, "[The UTLAs] are valuable because of their perspective, they interact with the students in a smaller group." Both instructors focused on the fact that the UTLAs had increased access to students and their perspective.

The UTLAs seemed to recognize their value as well. One UTLA elaborated in an interview:

I think [Dr. Cell] also likes that we get feedback from the students that we can give to her that they might not necessarily say to her. . . I I think sometimes they're, like, a lot more open with me ... so then we can kind of, like, gather their feedback and, like, filter it from, like, what it's like being a student.

The UTLAs were peers to the students, and therefore, students were more open and honest with them than they would be with an instructor. Also, the UTLAs played a role in "filtering" student feedback by determining which comments were important and communicating the student perspective in a way that was valuable to the instructor.

\section{UTLAs as consultants}

Quite frequently, the UTLAs were positioned as consultants, in that their assumed right or duty was to provide advice related to class activities, assignments, and exams to the instructor. The position of consultant is similar to that of informant but goes beyond that position; informants report information while consultants report information and make suggestions based on that information.

As part of the pedagogy course requirements, Dr. Cell positioned the UTLAs as consultants by assigning them the task at the end of the semester of choosing an assignment to revise for a future semester and explaining how and why they would make those revisions. Dr. 
Cell also positioned her UTLAs as consultants by asking them to review draft exams. For each exam (i.e., midterms and the final), the UTLAs and Dr. Cell talked about the entire draft exam together, and Dr. Cell listened to the UTLAs' thoughts on each question. Dr. Cell facilitated the conversation through questions such as "Is this too broad?" or "If you had to replace this with a different question related to [topic], what would you replace it with?" She often used the word "we" when asking for their thoughts, which demonstrated she considered preparing exams for students to be a group effort. In the final interview, Dr. Cell noted how helpful it was to have the UTLAs review the exams; she stated, "They picked up a bunch of things; some things I thought were super obvious they said they thought would be difficult, and some things I thought would be difficult they thought were super obvious." She recognized that the UTLAs provided her with a new perspective on the questions.

For Genetics, UTLAs were positioned as consultants on draft exams through e-mail communication. Due to limited time during in-person preparation meetings, Dr. Genetics sent each exam to one or two UTLAs and gave them the opportunity to review the exam and send questions or comments back via e-mail. She approached different UTLAs for each exam in order to spread out the extra effort required by this task and was always clear to them that reviewing the exams was optional based on time and interest. In an interview, Dr. Genetics noted:

They've got a great perspective on what the students may or may not know or how they might read things . . . but I try not to require them to give me feedback. Right. I try to make that, like, if you have the time and you want to do this, I would appreciate that, but they've already got a lot of work to do.

Thus, Dr. Genetics might have limited how often she positioned her UTLAs as consultants in order to respect their time.

Both Dr. Cell and Dr. Genetics repeatedly thanked the UTLAs for their feedback and input, demonstrating they respected and valued their ideas. The UTLAs confirmed in interviews that Dr. Cell and Dr. Genetics considered their opinions and were responsive to their suggestions. For example, one UTLA said about Dr. Genetics, "I think she does a good job . . . of respecting your ideas and having you be a part of making this course better," and another UTLA said, "We're not just her workers. We're more like working with her, not for her." Similarly, one UTLA said about Dr. Cell, "She definitely will actually make changes based on what we say and values our opinions," and another said, "She ... seemed like a really open person. She's always looking to improve, so I think that's made me really comfortable." The UTLAs' perceptions that their ideas were appreciated likely contributed to their willingness to act as consultants. In addition, by expressing continued appreciation and recognizing the efforts of the UTLAs, the faculty members established high levels of trust and respect key to maintaining confidentiality when granting students access to exam material.

\section{UTLAs as co-instructors}

I considered the UTLAs to be positioned as co-instructors when they were referred to as teachers by the faculty member or made collective decisions with the faculty member about teaching or grading. As co-instructors, instead of just sharing information or advice, UTLAs 
discussed teaching and learning with the faculty member as a team, and the team came to a group decision about instruction.

The UTLAs in both cases were responsible for working together to grade student exams, and Dr. Cell and Dr. Genetics trusted the UTLAs' judgment and gave them freedom in determining appropriate partial credit for open-ended questions. For Cell Biology, the UTLAs were each responsible for grading a separate page of the exam. After each exam, the group dedicated a meeting to "grade norm," in that they started grading together as a group to come to consensus on appropriate responses and partial credit. Dr. Cell let the UTLAs talk through the answers, and rather than tell them exactly how many points to assign, she allowed them to make the ultimate decision. Then, each UTLA took the remainder of their ungraded pages home to grade on their own time. The following week, the group re-combined the exams and discussed trends and problem areas.

For Genetics, the UTLAs also met as a group to grade exams for a long afternoon, directly following each exam. They completed all grading in person, together, sustained by ample snacks provided by Dr. Genetics. The grading sessions happened in a conference room, around a large table, which was different than their typical meetings. In interviews, the UTLAs confirmed the grading atmosphere was friendly and comfortable, and one UTLA noted that the grading meetings "helped me not view Dr. Genetics so much as an authority figure." Similar to grading discussions between Dr. Cell and her UTLAs, the Genetics UTLAs conferred with each other to discuss students' answers.

The UTLAs were also positioned as co-instructors by being provided with choice and flexibility related to how they approached working with students. Although Dr. Genetics gave her UTLAs a suggested plan for teaching each week, she made it clear the plan was flexible and that they could make their own decisions. As one UTLA said in an interview, "She definitely understands we're responsible and we will get everything done ... and she gives us a little bit of flexibility." Dr. Genetics trusted her UTLAs to do what was best for their students.

Sometimes, for the UTLAs, being positioned as a co-instructor overlapped with being positioned as a student, in that Dr. Cell and Dr. Genetics recognized their UTLAs as teachers, but as novice teachers learning to work with students. After the UTLAs for Cell Biology discussed the challenge of not always knowing the answers to students' questions, Dr. Cell reassured them that this challenge was not unique to them. She explained: "You guys are talking about . . . difficult things I think all teachers have to deal with, which is [that] we don't know everything. Those things happen just about for every teacher no matter how experienced." By admitting that she, and other teachers, face the same challenge, and by using the word "we," she positioned the UTLAs as part of a group that she is a part of, as well: teachers.

\section{UTLAs as co-creators}

At times, the UTLAs created instructional materials along with the faculty member, or on their own with support and feedback from the faculty member, which went beyond consulting with faculty to actually creating class content. The UTLAs were positioned as cocreators when the faculty instructors asked them to plan lessons, develop lecture or review material, and write exam questions.

For the Cell Biology course, the UTLAs helped to brainstorm exam questions, and by the end of the semester, they wrote one question themselves as a group. Dr. Cell also gave her 
UTLAs the opportunity to write a lesson plan, create presentation materials, and teach the class a topic of their own choice. In the Genetics course, the UTLAs were positioned as co-creators when they were given the opportunity to collaboratively develop an exam-review presentation before each exam or to create practice exam questions for review sessions.

The findings presented above illustrate in detail the five ways UTLAs were positioned in the data; I summarize the positions and associated acts and storylines in Table 4.2.

Table 2. Summary of UTLA positions and associated acts and storylines

\begin{tabular}{|l|l|l|}
\hline POSITION & STORYLINE & ACTS \\
\hline $\begin{array}{l}\text { UTLA as } \\
\text { (Faculty as } \\
\text { teacher) }\end{array}$ & $\begin{array}{l}\text { Faculty instructors are more } \\
\text { expert in both content and } \\
\text { pedagogy than UTLAs. }\end{array}$ & $\begin{array}{l}\text { UTLAs raised their hands to answer and } \\
\text { ask questions. Faculty members } \\
\text { explained course concepts or pedagogy. }\end{array}$ \\
\hline $\begin{array}{l}\text { UTLA as } \\
\text { informant } \\
\text { (Faculty as } \\
\text { information } \\
\text { seeker) }\end{array}$ & $\begin{array}{l}\text { UTLAs serve as a } \\
\text { communication channel } \\
\text { between faculty and students in } \\
\text { the course because of their } \\
\text { approachability and } \\
\text { accessibility. }\end{array}$ & $\begin{array}{l}\text { Faculty members asked questions such } \\
\text { as "How are things going?" UTLAs } \\
\text { reported on class-related experiences } \\
\text { with students. }\end{array}$ \\
\hline $\begin{array}{l}\text { UTLAs as } \\
\text { consultant } \\
\begin{array}{l}\text { Faculty as } \\
\text { advice seeker) }\end{array}\end{array}$ & $\begin{array}{l}\text { UTLAs provide pedagogical } \\
\text { advice and suggestions to } \\
\text { faculty based on their student } \\
\text { perspective and experiences. }\end{array}$ & $\begin{array}{l}\text { Faculty members asked the UTLAs to } \\
\text { review draft assignments or exams in } \\
\text { person and over e-mail. UTLAs and } \\
\text { faculty engaged in free-flowing and } \\
\text { collaborative conversation, building off } \\
\text { each other's suggestions. }\end{array}$ \\
\hline $\begin{array}{l}\text { UTLAs and } \\
\text { faculty as co- } \\
\text { instructors }\end{array}$ & $\begin{array}{l}\text { UTLAs support grading. UTLAs } \\
\text { are considered teachers. }\end{array}$ & $\begin{array}{l}\text { UTLAs and faculty members participated } \\
\text { in collaborative group discussion around } \\
\text { grading. Faculty members referred to the } \\
\text { UTLAs as teachers. Faculty members } \\
\text { noted flexibility and autonomy in the } \\
\text { UTLAs' work. }\end{array}$ \\
\hline $\begin{array}{l}\text { UTLAs and } \\
\text { creators }\end{array}$ & $\begin{array}{l}\text { UTLAs help to create } \\
\text { instructional materials, } \\
\text { including exams. }\end{array}$ & $\begin{array}{l}\text { Faculty members gave the UTLAs an } \\
\text { opportunity to develop instructional } \\
\text { materials and exam questions. UTLAs } \\
\text { and faculty members engaged in } \\
\text { collaborative group discussion. }\end{array}$ \\
\hline
\end{tabular}

\section{DISCUSSION}

Through analyzing data collected during a semester of UTLA-faculty interactions for two different courses, I provided examples of how the UTLAs were positioned as students, informants, consultants, co-instructors, or co-creators. I offered a dynamic view of UTLA-faculty 
partnerships and showed that, despite each case having relatively consistent interactional norms, there was still fluidity in how the UTLAs were positioned.

Positioning theory suggests that positions are mediated through discourse, so this study attempted to reveal some of the more overarching discourse patterns in the UTLA-faculty interactions. Most of the time, faculty determined UTLA positioning by asking questions or giving explicit directions. For example, "How are things going?" more often positioned the UTLAs as informants, while "What do you guys think?" more often positioned the UTLAs as consultants. However, the data also revealed that the UTLAs positioned themselves at times, potentially because they gained the sense that position was appropriate in that particular moment based on interactional norms.

One could infer that I presented the UTLA positions in order from least to greatest collaboration with the faculty member, or from least to most power that the faculty member allowed the UTLAs to have in terms of instruction. However, in doing so, I did not intend to rank the positions in terms of desirability. Positioning UTLAs as co-instructors or co-creators does allow for the UTLAs to have more power in the instructional process, which is something to strive for in a UTLA-faculty partnership. Nevertheless, positioning the UTLAs as students may still, at times, be appropriate and beneficial to provide them with the structure and support they need in order to improve their teaching. A collaborative instructional partnership does not necessarily require the UTLAs and the faculty to have equal power; rather, they should work together to negotiate power based on time, experience, ability, and goals (Cook-Sather et al., 2014).

Other scholars have characterized levels of UTLA-faculty partnerships (Sabella et al., 2016), and my findings help to expand upon these characterizations by providing a more detailed account of UTLA-faculty interactions and the variety and fluidity in UTLA positioning. In mapping the interactional norms for Case 1 and Case 2 onto Sabella et al.'s (2016) characterizations, I would characterize Case 1 as fully collaborative, in that the UTLAs and Dr. Cell worked together on instruction, and Case 2 as faculty-driven collaboration, in that Dr. Genetics requested UTLA input and feedback but determined the outcome. However, labeling or categorizing UTLA-faculty partnerships in specific ways might limit our understanding of the complexity of those partnerships and lead us to fail to notice variation. Considering moment-by moment UTLA positioning may be more useful to create an accurate depiction of UTLA-faculty partnerships. As van Langenhove and Harré (1999) put it, "the concept of positioning can be seen as a dynamic alternative to the more static concept of a role" (p. 14).

\section{IMPLICATIONS: CREATING COLLABORATIVE UTLA-FACULTY INSTRUCTIONAL PARTNERSHIPS}

This study reveals various implications for those who are interested in establishing or supporting UTLA-faculty instructional partnerships. Faculty members should reflect on how they are positioning their UTLAs. The UTLAs should reflect on how they are being positioned or how they are positioning themselves and challenge positioning that might be limiting their involvement in the instructional process.

There were also a number of factors and contextual features that may have impacted how the UTLAs were positioned in the two cases presented here. Although I do not intend to communicate any causal claims, I suggest instructor experience, UTLA role, UTLA pedagogical 
training, and format and structure of meetings had an influence on the positioning of the UTLAs in their interactions with the faculty members.

\section{Instructor experience with the course}

In the semester during which this study took place, Dr. Cell and Dr. Genetics had different levels of experience with the courses they were teaching. Fall 2018 was Dr. Cell's first time teaching the cell biology course; thus, she may have been more open to critique, input, cocreation, and collaborative problem solving. In contrast, Dr. Genetics had taught the Genetics course for several semesters and had created the materials that the UTLAs were using in their teaching. Thus, the UTLAs may have viewed Dr. Genetics as more of an expert and perceived the course as more established. Instructor experience with a course may impact how often the faculty member opens up space for the UTLAs to make suggestions or discuss improvements to the course.

\section{UTLA role}

The UTLAs for the two cases performed very different roles in terms of working with students. In both cases, the UTLAs led office hours for students and helped the instructors to grade assignments and exams. However, in terms of in-class roles, in Case 1, the UTLAs facilitated small-group discussions during the large lecture taught by Dr. Cell, whereas the Genetics UTLAs led their own discussion sections. In Case 1, during circumstances when students in the class worked on activities, the UTLAs and Dr. Cell took on similar teaching roles in that they all walked around and facilitated discussion. Thus, Dr. Cell may have been more likely to position the UTLAs as co-instructors while discussing their teaching. The Genetics UTLAs did not teach alongside Dr. Genetics; rather, they taught separately and independently. This separation may have limited how often they were positioned as co-instructors and increased how often they were positioned as informants or consultants because they were the only ones with eyes into their specific discussion section.

\section{UTLA pedagogical training}

The UTLAs in Case 1 and Case 2 participated in different pedagogical preparation courses. For the Cell Biology UTLA pedagogy course, the UTLAs were receiving course credit for their participation, so they were often positioned as students in that setting. However, through activities such as revising instructional materials, the UTLAs were positioned as informants, consultants, and co-creators. Also, discussions around pedagogy often led to the UTLAs being positioned as co-instructors. Since Dr. Cell was leading the pedagogy course, there were additional opportunities for her to position the UTLAs in more collaborative ways and have more time to establish rapport. In Case 2, the UTLAs had already taken their required pedagogy course in a prior semester, and Dr. Genetics was not the instructor for that course. Disconnect between pedagogical training and UTLA preparation meetings with the faculty member may limit how much the UTLAs and faculty collaborate around instruction. 


\section{UTLA-faculty meeting format and structure}

Meeting location and room arrangement may influence how the UTLAs interact with the faculty member and with each other. By sitting around a table together, the Cell Biology UTLAs and Dr. Cell established a feeling of community, which may have encouraged more open discussion. The Genetics meetings were held in a classroom where the UTLAs sat in rows, sometimes hidden behind computer screens, and this set-up may have led them to feel less inclined to discuss instruction with each other and Dr. Genetics. However, the group of Genetics UTLAs (11) was more than twice as large as the group of Cell Biology UTLAs (5), so with more people, there were constraints in room arrangement and individual speaking time. Faculty members should consider how they can arrange the room and structure the conversation to provide individual UTLAs a voice.

Overall, even though these cases of UTLA-faculty partnerships differed, what I found to be most influential in terms of their collaborative nature was the recognized notion of a "teaching team." The UTLAs in both cases were never positioned as helpers or workers, but instead as novice colleagues with valid opinions, perspectives, and expertise. Even when positioning the UTLAs as students, Dr. Cell and Dr. Genetics communicated a focus on the UTLAs' professional development; rather than talking at them, they were talking with them. Faculty should carefully consider how their words and actions, and the responsibilities they designate to their UTLAs, while respecting their time and ability, communicate (or don't communicate) the notion that UTLAs are part of a "teaching team."

This research was successfully reviewed according to the University's Institutional Review Board.

\section{ACKNOWLEDGEMENTS}

I am very grateful for the insightful feedback and guidance I received on this study and earlier versions of this manuscript from Daniel Levin, Chandra Turpen, Andrew Elby, Andrew Brantlinger, and Todd Cooke.

\section{NOTES}

1. I use the term "undergraduate teaching and learning assistants" (UTLAs) to refer to undergraduates who facilitate student-centered instruction in a lecture course or recitation sections associated with a lecture course. I build off literature related to the "learning assistant" model (Otero et al., 2010), "peer led team learning" model (Gafney \& Varma-Nelson, 2008), "peer learning assistant" model (Groccia \& Miller, 1996), and other literature that may use terms such as "undergraduate teaching assistants" or "peer facilitators." Different terms may represent different roles; therefore, when describing specific models, I use the term associated with that model. When synthesizing across models and terminology, I use the overarching term UTLA.

\section{NOTE ON CONTRIBUTOR}

Hannah Jardine supports faculty, graduate-student, and undergraduate-student development in teaching and manages the Academic Peer Mentoring Program as a Postdoctoral Associate at the University of Maryland's Teaching and Learning Transformation Center (TLTC). Her research 
examines how undergraduate teaching and learning assistants can work with faculty to support course reform.

\section{REFERENCES}

Anderson, K. T. (2009). Applying positioning theory to the analysis of classroom interactions: Mediating micro-identities, macro-kinds, and ideologies of knowing. Linguistics and Education, 20(4), 291-310.

Astin, A. W. (1993). What matters in college? Four critical years revisited. San Francisco, CA: Jossey-Bass.

Bovill, C. (2014). Students and staff co-creating curricula: An example of good practice in higher education? In E. Dunne \& D. Owen (Eds.), The student engagement handbook: Practice in higher education (pp. 461-475). Bingly, UK: Emerald Group Publishing Limited.

Bovill, C., Cook-Sather, A., \& Felten, P. (2011). Students as co-creators of teaching approaches, course design and curricula: Implications for academic developers. International Journal for Academic Development, 16(2), 133-145. https://doi.org/10.1080/1360144X.2011.568690

Close, E. W., Conn, J., \& Close, H. G. (2016). Becoming physics people: Development of integrated physics identity through the Learning Assistant experience. Physical Review Physics Education Research, 12(1), 010109-1-18.

Cook-Sather, A. (2008). What you get is looking in a mirror, only better: Inviting students to reflect (on) college teaching. Reflective Practice, 9(4), 473-483.

Cook-Sather, A. (2009). From traditional accountability to shared responsibility: The benefits and challenges of student consultants gathering midcourse feedback in college classrooms. Assessment \& Evaluation in Higher Education, 34(2), 231-241. https://doi.org/10.1080/02602930801956042

Cook-Sather, A. (2010). Students as learners and teachers: Taking responsibility, transforming education, and redefining accountability. Curriculum Inquiry, 40(4), 555-575. https://doi.org/10.1111/j.1467-873X.2010.00501.x

Cook-Sather, A. (2011a). Layered learning: Student consultants deepening classroom and life lessons. Educational Action Research, 19(1), 41-57. https://doi.org/10.1080/09650792.2011.547680

Cook-Sather, A. (2011b). Lessons in higher education: Five pedagogical practices that promote active learning for faculty and students. Journal of Faculty Development, 25(3), 33-39.

Cook-Sather, A. (2014). Multiplying perspectives and improving practice: What can happen when undergraduate students collaborate with college faculty to explore teaching and learning. Instructional Science, 42(1), 31-46. https://doi.org/10.1007/s11251-013-9292-3

Cook-Sather, A., Bovill, C., \& Felten, P. (2014). Engaging students as partners in learning and teaching: A guide for faculty. San Francisco, CA: Jossey-Bass.

Davenport, F., Amezcua, F., Sabella, M. S., \& Van Duzor, A. G. (2017). Exploring the underlying factors in learning assistant - faculty partnerships. Physics Education Research Conference Proceedings, 104-107. 
Felten, P., Bagg, J., Bumbry, M., Hill, J., Hornsby, K., Pratt, M., \& Weller, S. (2013). A call for expanding inclusive student engagement in SoTL. Teaching and Learning Inquiry, 1(2), 63-74. https://doi.org/10.20343/teachlearninqu.1.2.63

Gafney, L., \& Varma-Nelson, P. (2008). Peer-led team learning: Evaluation, dissemination, and institutionalization of a college level initiative. Netherlands: Springer.

Harré, R., \& Moghaddam, F. (Eds.). (2003). The self and others. Westport, CT: Praeger.

Harré, R., Moghaddam, F., Cairnie, T. P., Rothbart, D., \& Sabat, S. R. (2009). Recent advances in positioning theory. Theory \& Psychology, 19(1), 5-31. https://doi.org/10.1177\%2F0959354308101417

Healey, M., \& Healey, R. L. (2018). 'It depends': Exploring the context-dependent nature of students as partners' practices and policies. International Journal for Students as Partners, 2(1), 1-10. https://doi.org/10.15173/ijsap.v2i1.3472

Healey, M., Flint, A., \& Harrington, K. (2014). Engagement through partnership: Students as partners in learning and teaching in higher education. York: Higher Education Academy.

Jardine, H. E., \& Friedman, L. A. (2017). Using undergraduate facilitators for active learning in organic chemistry: A preparation course and outcomes of the experience. Journal of Chemical Education, 94(6), 703-709. https://doi.org/10.1021/acs.jchemed.6b00636

Knight, J. K., Wise, S. B., Rentsch, J., \& Furtak, E. M. (2015). Cues matter: Learning assistants influence introductory biology student interactions during clicker-question discussions. CBE-Life Sciences Education, 14(4), 1-14. https://doi.org/10.1187/cbe.15-04-0093

Kopp, S. E. (2000). Undergraduate peer assistants in a large lecture course. Physics Education, 35(6), 423-427. https://doi.org/10.1088/0031-9120/35/6/308

Kuh, G., Kinzie, J., Schuh, J. H., \& Whitt, E. J. (2010). Student success in college: Creating conditions that matter. San Francisco: Jossey-Bass.

Little, S. (2011). Staff-student partnerships in higher education. London: Continuum.

Mercer-Mapstone, L., Dvorakova, S. L., Matthews, K. E., Abbot, S., Cheng, B., Felten, P., Knorr, K., Marquis, E., Shammas, R. \& Swaim, K. (2017). A systematic literature review of students as partners in higher education. International Journal for Students as Partners, 1(1), 1-23. https://doi.org/10.15173/ijsap.v1i1.3119

Merriam, S. (1998). Qualitative research and case study applications in education. San Francisco, CA: Jossey-Bass.

Miles, M. B., \& Huberman, A. M. (2014). Qualitative data analysis (3rd ed.). Thousand Oaks, CA: Sage.

Miller, J. E., Groccia, J. E., \& Miller, M. S. (2001). Student-assisted teaching: A guide to facultystudent teamwork. Bolton, MA: Anker.

Otero, V., Pollock, S., \& Finkelstein, N. (2010). A physics department's role in preparing physics teachers: The Colorado learning assistant model. American Journal of Physics, 78(11), 1218-1224. https://doi.org/10.1119/1.3471291

Pavlacic, J., Culp, M., Harvey, S., Cathey, C., \& Buchanan, E. (2018). Using undergraduate learning assistants to aid in course redesign. Modern Psychological Studies, 23(2), Article 2.

Preszler, R. W. (2009). Replacing lecture with peer-led workshops improves student learning. CBE-Life Sciences Education, 8(3), 182-192. https://doi.org/10.1187\%2Fcbe.09-01-0002 
Sabella, M. S., Van Duzor, A. G., \& Davenport, F. (2016). Leveraging the expertise of the urban STEM student in developing an effective LA Program: LA and instructor partnerships. 2016 Physics Education Research Conference Proceedings, 288-291.

Sorenson, D. L. (2001). College teachers and student consultants: Collaborating about teaching and learning. In J. E. Miller, J. E. Groccia, \& M. S. Miller (Eds.), Student-assisted teaching: A guide to faculty-student teamwork (pp. 179-183). Bolton, MA: Anker.

Strauss, A., \& Corbin, J. (1990). Basics of qualitative research: Grounded theory procedures and techniques. Newbury Park, CA: Sage.

Tinto, V. (1993). Rethinking the causes and cures of student attrition. Chicago: University of Chicago Press.

van Langenhove, L., \& Harré, R. (1999). Introducing positioning theory. In R. Harré \& L. van Langenhove (Eds.), Positioning theory: The moral context of intentional actions (pp. 1431). Oxford, UK: Blackwell.

Werder, C., \& Otis, M. M. (2010). Engaging student voices in the study of teaching and learning. Sterling, VA: Stylus. 